\title{
RESEARCH
}

Open Access

\section{Need and inequality in the use of health care services in a fragmented and decentralized health system: evidence for Argentina}

Alfredo Palacios,, Natalia Espinola and Carlos Rojas-Roque

\begin{abstract}
Background: The high fragmentation and decentralization in the provision of health care services that characterizes Argentina's health system, as well as the economic and social inequalities, challenge the achievement of the Universal Health Coverage (UHC). The objective of this study is to measure socioeconomic-related inequality and horizontal inequity in the use of health care services in Argentina as well as identify the factors that contribute to these disparities.
\end{abstract}

Methods: The 2013 National Risk Factor Survey, developed by the Ministry of Health of Argentina, was used to measure socioeconomic-related inequality and inequity in the use of health care services through concentration curves, the Erreygers concentration index, and the index of horizontal inequity. Econometric micro-decomposition was applied to estimate the contribution of each determining factor to inequality in the use of health care services.

Results: The Erreygers concentration index for the use of health care services was 0.1223 , evidencing pro-rich inequalities. By adding variables of health care needs, the horizontal inequity index was 0.1296. Non-need factors such as education and health coverage with social security increase pro-rich inequality.

Conclusions: The Argentine health system shows pro-rich inequality in the use of health care services. It is necessary to design strategies to improve articulation between the three coverage subsectors and national, provincial, and municipal governments to keep the commitment of "not leaving anyone behind." The results showed here could provide lessons for countries with similar contexts and challenges in public health.

Keywords: Inequality, Inequity, Health care disparities, Utilization of health care, Argentina

\footnotetext{
*Correspondence: apalacios@iecs.org.ar

Institute for Clinical Effectiveness and Health Policy (IECS), Doctor Emilio

Ravignani 2024, Buenos Aires, Argentina
}

C C The Author(s). 2020 Open Access This article is licensed under a Creative Commons Attribution 4.0 International License, which permits use, sharing, adaptation, distribution and reproduction in any medium or format, as long as you give appropriate credit to the original author(s) and the source, provide a link to the Creative Commons licence, and indicate if changes were made. The images or other third party material in this article are included in the article's Creative Commons licence, unless indicated otherwise in a credit line to the material. If material is not included in the article's Creative Commons licence and your intended use is not permitted by statutory regulation or exceeds the permitted use, you will need to obtain permission directly from the copyright holder. To view a copy of this licence, visit http://creativecommons.org/licenses/by/4.0/ The Creative Commons Public Domain Dedication waiver (http://creativecommons.org/publicdomain/zero/1.0/) applies to the data made available in this article, unless otherwise stated in a credit line to the data. 


\section{Background}

Equity constitutes a social value and a guiding principle of political health action [1]. The Alma-Ata Declaration of 1978, the Ottawa Charter of 1986, and, more recently, the 2030 Agenda for the achievement of the Sustainable Development Goals (SDGs) are a call for social equity and reflect the commitment to design social and health policies with an equity approach. Expressly, objective 10 and goal 3.8 of objective 3 of the SDGs point to the reduction of inequalities in all sectors and achieve Universal Health Coverage (UHC) [2]. Thus, equity as a social value has become increasingly important in international policy agendas.

Since the early 1990s, several Latin American countries have initiated reforms intending to strengthen health systems, reduce inequalities in access to health care services, and expanding the UHC [3]. However, given the gap between the medically possible and financially feasible, some type of explicit or implicit rationing has been inevitable, and on other occasions, the resources are not properly allocated. Consequently, the expansion of coverage and the reduction of health inequalities remains a pending issue in Latin American countries [4].

Argentina is an upper-middle-income country located in South America with a population of 44 million, where $92 \%$ live in cities. Noncommunicable diseases account for more than $78 \%$ of the burden of disease, and it is one of the leaders in the Latin American region concerning health care expenditure per capita [5]. Compared with other countries in the region, its health care system performs well on several key indicators (for further details, see Table S1 in the Supplementary material). However, there are still some challenges on the public agenda related to both equity and efficiency, as in many other countries in Latin America [3, 6].

In the decade of the 1990s, Argentina underwent a profound reform of its health care system, as well as other countries in Latin America. The purpose was to establish a mechanism that ensured an efficient allocation of resources and guaranteed a more comprehensive provision of health care services based on equity and population needs. During this period, Argentina adopted an ambitious range of reforms, mainly focusing on decentralization and restructuring of social security systems [7].

Currently, the Argentine health system is characterized by decentralization in the public health sector and fragmentation in its social insurance mechanisms, both in the sources of funds and in the structure of service provision [8]. Decentralized functions from the nation to the provinces (and in some cases from the provinces to the municipalities) include fundraising, resource management, setting health goals, setting health strategies and priorities. Health service coverage is fragmented into three subsectors: the public subsector (national, provincial, and municipal), the social insurance subsector (Obras Sociales), and the private health subsector. Fragmentation occurs because there are no coordination and cooperation mechanisms in terms of management, financial, and health risks among the three subsectors.

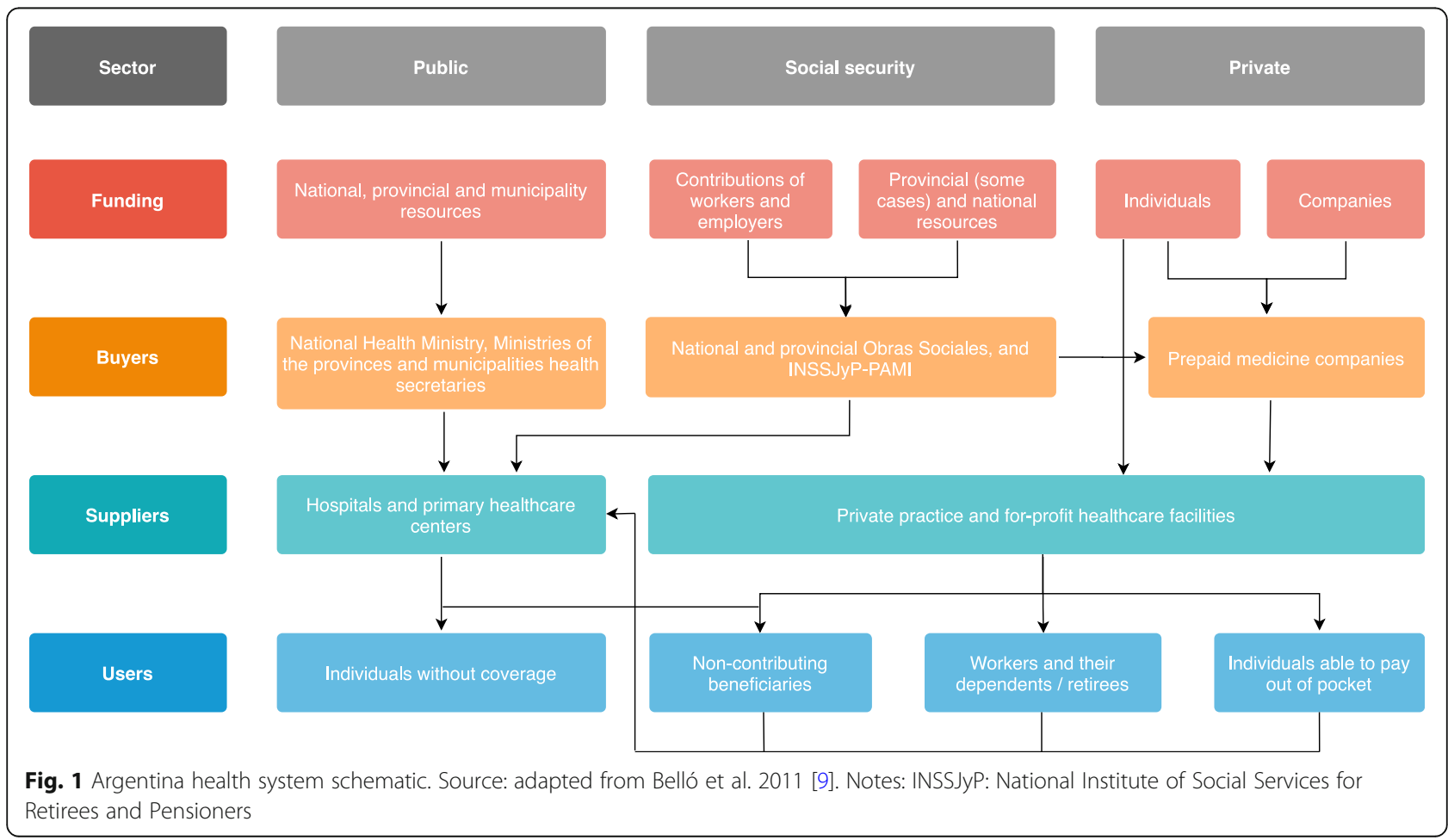


Figure 1 presents the sources from which funds are collected, the organization of insurance structures and risk-sharing schemes, the management mechanisms of the funds, and how these funds translate into the provision of health care services, for each of the three subsectors mentioned [9-11].

The public health subsector is financed by national, provincial, and municipal funds, which contribute to the Ministries or Secretaries of Health at each of these levels. Within this model, there is a notable decentralization in resource management, fundraising, and the establishment of health strategies and priorities. Thus, each province has the autonomy to define and establish a health care strategy for its inhabitants. In terms of provision, the public subsector has a network of public hospitals and primary health care centers that are owned and managed by provincial and municipal authorities. These hospitals and primary health care centers provide free care to anyone who demands it, in general, people without health insurance $[6,9,12]$.

Social security, the most important subsector within the health system, is organized around three large groups: i) 269 Obras Sociales Nacionales (OSNs); ii) 24 Obras Sociales Provinciales (OSPs); and iii) the National Institute of Social Services for Retirees and Pensioners (INSSJyP - PAMI, acronym in Spanish) $[9,11]$. OSNs cover over 15 million Argentine salaried workers and their families according to economic activity, whereas OSPs are in charge of providing health care services to public employees in their jurisdiction. The INSSJyP, alternatively, provides coverage to more than 5 million retirees of the national pension system and their families. Currently, 70\% of the 269 OSNs have less than 30,000 beneficiaries, and $80 \%$ have less than 100,000, which makes them inefficient due to their high administrative costs; in addition, their risk pools are highly unstable to deal with high-cost events [7].

The private health subsector has as a financing mechanism the out-of-pocket payment, destined to the copayment of services provided under some provincial and national Obras Sociales, and the fees and complementary payments of the prepaid insurance provided by prepaid medicine companies, concentrated in four firms with high market power [9-11].

According to the 2010 Population Census, 36.1\% of the population does not have formal health coverage; 46.4\% had coverage of Obras Sociales; private insurance that was accessed through contributions to Obras Sociales covered an additional 10.6\%; 5.1\% accessed prepaid medicine through voluntary insurance payment; only $1.8 \%$ were beneficiaries of specific state programs and plans [13]. In terms of total health expenditure, $29 \%$ corresponds to public expenditure, $41 \%$ corresponds to social security expenditure, and the remaining $30 \%$ is private expenditure (which includes out-of-pocket expenses in prepaid insurance, co-payments, and uncovered care). Within public sector expenditure, 67\% corresponds to provincial spending [14].

In general, the Argentine health system represents an uncoordinated model for the management of plans and funds, where the contributors with the greatest financial capacity do not direct their contributions towards the subsector that absorbs the most significant financial and health risk, being captured by those subsectors with less financial exposure [7, 11]. This phenomenon of "skimming" between financial coverage systems is complemented by the presence of unwanted cross-subsidies from the public subsector to the rest of the subsectors [15]. That is, the public subsector also provides care to people who have formal insurance, and given their difficulties in billing for the services provided, these practices are challenging to collect and reinvest. All of these aspects reduce the possibilities of individuals without coverage to obtain health care, with implications for the equity of the system.

In particular, the decentralization of the Argentine health system, as well as the absence of mechanisms for redistribution of resources between jurisdiction, leads to significant disparities in terms of public health care expenditure [16], the availability of medical doctors and nurses [17] and infant and maternal mortality rates [18] at the provincial level. By case, the mortality gap in colon-rectum and cervical cancer is 7 and 5.4 times, respectively, between the wealthiest and most impoverished provinces in the country [19]. In the local literature, these cancer mortality gaps have been associated with different provincial capacities for early detection, diagnosis, and treatment of patients [20, 21].

Numerous studies have well documented socioeconomic inequalities in Argentina [22-26]. This literature suggests that while socioeconomic inequality is considerable (Gini index was 0.412 in Argentina in 2017) [5], it has declined in recent decades thanks to the implementation of cash transfer programs and the growth of labor formality. While inequalities in access to health care services have been widely described at the local level [27-37], few studies have analyzed the socioeconomic-related inequality in health care variables through the methodological approach presented in this work [38-40].

Nowadays, the Argentine health system is in search of providing effective universal health coverage, meaning that people actually receive prioritized health care services. Among the specific objectives set to achieve this goal, the reduction of disparities in access to health services is one of them [7]. However, this constitutes a significant challenge due to system fragmentation and decentralization - as well as the absence of subsystems integration - leading to inefficiencies and inequities in health [6]. In this context, the objective of this study is 
to measure socioeconomic-related inequality and horizontal inequity in the use of health care services in Argentina as well as identify the factors that contribute to explain these disparities.

\section{Methods}

\section{Study design and data}

This analytical study used data from the Third National Survey of Risk Factors 2013 (ENFR 2013) designed and compiled by the National Institute of Statistics and Census (INDEC) and the Ministry of Health of Argentina. The ENFR collects information on risk factors, health care utilization, and prevalence of central non-communicable diseases, among others. The sample design of the ENFR is probabilistic, stratified, and multi-stage and is representative at the national and provincial levels with 5000 or more inhabitants. This survey included 32,365 people 18 years of age or older, living in particular households in Argentina. The methodological aspects of the survey to consider for reading the results can be found in the final results report [41].

\section{Dependent variable}

The study-dependent variable is a dichotomous variable that measures the use of health care services (yes / no). The variable is constructed based on the questions referring to whether the individual in the last 30 days consulted a healthcare professional, including a physician (clinician or specialist), dentist, psychologist, psychoanalyst or psychiatrist, or others. The use of health care services meant the respondent reported having consulted at least one of the previously mentioned services.

\section{Independent variables}

The independent variables of the study were selected based on Andersen's theoretical model of behavior on the use of health care services [42, 43], consistent with other studies that analyze the use of health care services at a regional and local level [44-46]. This model indicates that the use of health care services is a function of three major factors: predisposing factors, enabling factors, and need factors. The predisposing factors are composed of sociodemographic characteristics, characteristics of the social structure, and beliefs in people's health. The enabling factors correspond to the means and capacity of people to use health care services both at the individual and community levels. The need factors correspond to variables that predispose the use of health care services due to the health problems of the individual.

The study included the following variables as predisposing factors: sex (male / female), age in ranges (18-24 / 25-34 / 35-49 / 50-64 / 65 or more), married or united (yes / no), educational level in ranges (up to incomplete primary / complete primary and incomplete secondary / complete secondary or more) and household size in ranges (1-3 members / 4-6 members / 7 members or more). According to the ENFR 2013, all variables were measured by self-report.

The following variables were included for the enabling factors: type of health coverage (social security insurance / private insurance / public insurance), currently employed (yes / no), income per capita quintiles (I (poorest quintile), II, III, IV, V (richest quintile)), urban populations (between 5000 and 100,000 inhabitants / between 100,001 and 500, 000 inhabitants / between 500,001 and 1.5 million inhabitants / more than 1.5 million inhabitants) and geographical region (Great Buenos Aires / Pampeana / Northwest / Northeast / Cuyo / Patagonica). The individual was considered as currently employed if they worked at least $1 \mathrm{~h}$ in economic activities during the reference week. Household income includes income from work, retirement, unemployment insurance, scholarships, and other sources of income during the month prior to the survey. In order to estimate the missing values in the income variables, the hierarchical hot-deck approach was used as an imputation method [47]. Because ENFR 2013 does not report information required to estimate the income per capita adjusted by equivalent adult (sex and age of household members), income quintiles were constructed using the income per capita (dividing the total household income by the number of household members).

The grouping of jurisdictions used is in line with the framework of the National Statistical System, that categorizes the country into six statistical regions [47]. The following variables correspond to need factors: selfperceived health status (excellent / very good / good / regular / bad), problems with mobilization (yes / no), feeling lonely or depressed (yes / no), level of physical activity (intense / moderate / low), pain or physical discomfort (yes / no), presence of high blood pressure (yes / no), presence of diabetes mellitus (yes / no), presence of chronic obstructive pulmonary disease (yes / no), presence of chronic kidney disease (yes / no) and cumulative number of chronic diseases suffered $(0 / 1 /$ $2 / 3$ or more). The level of physical activity was categorized according to the recommendations of the International Physical Activity Questionnaire (IPAQ). The cut-off points for the different categories are detailed on the IPAQ website or in the ENFR use document $[47,48]$.

\section{Statistical analysis}

The processing and statistical analysis of the ENFR 2013 database was performed using the Stata ${ }^{\circ}$ v14.2 statistical software (Stata Corporation, College Station, Texas, USA). The svy command was used to specify the 
weighting factors of the ENFR 2013. For all analyses, statistical significance was considered if $p<0.05$.

Absolute frequencies and weighted proportions described the socio-demographic characteristics of the population. Absolute frequency, weighted proportions, and the $95 \%$ confidence interval described the use of health care services. The concentration curve (CC), the Erreygers concentration index (ECI) and the horizontal inequity index (HI) were computed to measure inequality in the use of health services.

The concentration curve $(\mathrm{CC})$ describes the relationship between the cumulative percentage of the population, ordered by their per capita income, and the cumulative percentage of the use of health services with the diagonal line of equality. Inequality is estimated according to the concavity or convexity of the curve. The further the $\mathrm{CC}$ moves away from the line of equality, the greater the degree of inequality. If the $\mathrm{CC}$ is below the equality line, there is greater use of health services for the population with higher levels of per capita income. When the CC is above the equality line, it indicates a more significant use by the part of the population with lower per capita income [49].

Nevertheless, a CC does not give a measure of the magnitude of inequality that can be compared across periods, or other relevant variables. For this, the Concentration Index $(\mathrm{CI})$, which is directly related to the $\mathrm{CC}$, does quantify the degree of socioeconomicrelated inequality in a health variable [50]. The CI is defined as twice the area between the concentration curve and the line of equality (the 45-degree line). Therefore, when there is no socioeconomic-related inequality, the $\mathrm{CI}$ is zero. If the CC lies above the line of equality, the $\mathrm{CI}$ takes a negative value, indicating disproportionate concentration of the health variable among poor people; if the $\mathrm{CC}$ lies below of the line of inequality, the CI takes a positive value, and it means that there is a disproportionate concentration of the health variable among rich people. In this case, a positive value of the $\mathrm{CI}$ means that the use of health care services is higher among the rich. Given the dichotomous characteristic of the dependent variable, the ECI was computed for the methodological advantages in relation to the standard concentration index [51]. However, the interpretation of the index is the same. Mathematically, ECI is obtained:

$$
E C I(y)=\frac{1}{n} \sum_{i=1}^{n}\left[\frac{4 a_{i}}{\left(a^{\text {max }}-a^{\text {min }}\right)}\left(2 R_{i}-1\right)\right]
$$

In which $a_{i} \in\left[a^{\min }, a^{\max }\right]$ denotes the dichotomous variable with the limit values 0 and 1 , and $R_{i}-1$ denotes the fractional range of per capita income. For any ECI, the values it takes range from -1 to 1 , which reflects the variability and strength of the relationship between the variables studied. The values are positive (negative) when there is greater use of health care services for the population with higher (lower) levels of per capita income.

Since variations in the use of health care services due to differences in health status are unavoidable (healthy people use health services less in comparison to nonhealthy people), income-related inequality itself is not considered inequity in health care services use. The HI compares the actual distribution of the use of health care services with the expected use according to the health needs of individuals to assess inequities. Therefore, $\mathrm{HI}$ measures the degree to which health care use is related to income after controlling for differences in need across the income distribution.

For the estimation of the HI, the use of health care services was standardized following the approach of indirect standardization with non-linear models proposed by O'Donnell [49]. When the health variable is dichotomous, as in our case, this approach suggests using probit or logit models for the standardization of the use of health care services, because it best fits the non-linearity of the distribution of the variable.

There were two stages for the estimation of the HI. First, the use of health care services was estimated using a non-linear model through probit estimation, taking as independent variables a vector of need variables and a vector of no need variables as follows:

$$
y_{i}=\alpha+\beta \ln \left(i n c_{\mathrm{i}}\right)+\sum_{k} \delta_{k} X_{k 1}+\sum_{p} \phi_{p} Z_{p 1}+\mu_{i}
$$

In which $y_{i}$ is the observed use of the health care services of an individual $i, i n c_{i}$ is the per capita income of the individual $i, X$ it is a vector of need variables for the use of health care services, $Z_{p 1}$ is a vector of control variables of no need for the use of health care services (predisposing and enabling factors), $\alpha, \beta, \delta_{k}$ y $\phi_{p}$ are model parameters and $\mu_{i}$ is the error term. This model allows predicting the probability of using health care services by individuals, i.e., the probability of using health care services that the individual should consume considering that he or she is treated the same to other people that have the same health care needs.

Second, the standardized demand for the use of health care services $\left(\hat{y}_{i}^{1 s}\right)$ was estimated using the values of $y$ predicted by standardizing the $X$ variables (health care necessity factors) while simultaneously controlling the $Z$ variables (no need factors: predisposing and enabling factors) and the per capita income variable, which arise from the previous regression. Mathematically, 


$$
\hat{y}_{i}^{x}=\hat{\alpha}+\hat{\beta} \ln (i \bar{n} c)+\sum_{k} \hat{\delta}_{k} X_{k 1}+\sum_{p} \hat{\phi}_{p} \bar{Z}_{p 1}
$$

Then it was calculated $\hat{y}_{i}^{1 s}=y_{i}-\hat{y}_{i}^{x}+y$, in which $\hat{y}_{i}^{1 s}$ is the standardized demand for health care services, $y_{i}$ is the observed demand for the use of the health care services of individual $i, \hat{y}_{i}^{x}$ is the expected demand given $X$ and $y$ It is the sample mean of real demand of health care services. After performing the standardization, ECI was calculated for both the current demand $\left(C_{m}\right)$ and predicted demand $\left(C_{p}\right)$ and $\mathrm{HI}$ was estimated as follows:

$$
H I=2 \int_{0}^{1}\left[L_{p}(p)-L_{m}(p)\right] d p=C_{m}-C_{p}
$$

In which $L_{p}(p)$ is the CC for the predicted demand for health care services and $L_{m}(p)$ is the $\mathrm{CC}$ for the actual demand. The values of the IH range between -2 and 2 . When the $\mathrm{HI}$ is positive, it suggests that the inequality standardized by necessity shows inequities that favor the richest individuals.

Finally, econometric micro-decomposition methods were applied to determine the contribution of each factor to inequality in the use of health services, following the methodology developed by Van Doorslaer et al. [17, 18]. The decomposition was performed by ordinary least squares regression model, based on a linear approximation of the partial effects of each factor evaluated in the sample means. This approach allows us to identify which factors are associated with the pro-rich and pro-poor use of health care services and approximate their contribution to ECI.

\section{Results}

Table 1 shows the main characteristics of the total population under study $(n=32,365) .52 .6 \%$ of adults are female, between the ages of 35-49 years (26.6\%) and half the population completed high school or a higher educational level (51.9\%). Most adults have health coverage through social security (57.0\%), and approximately three out of five adults are employed (62.7\%). Nearly half reported having good health (42.9\%), and just over half of them indicated having a low level of physical activity (54.7\%). Half of the adults reported having used health care services $(49.4 \%)$. Women, the elderly, and adults living in homes with 1 to 3 members report greater use of health care services compared to men, younger adults, and adults living in larger households, respectively. Likewise, adults covered by social security insurance and those who are unemployed reported greater use of health care services compared to those who are affiliated with other health insurance or are employed. Greater use of health care services was reported as income per capita increases, self-perception of health status is worse, or the number of chronic diseases increases. There are no differences in the use of health care services according to the size of the population grouping or according to geographical region.

Figure 2 shows the $\mathrm{CC}$ for the use of health care services estimated for some selected factors: type of health coverage, educational level, household size, and presence of pain or physical discomfort. In most of CC, a pro-rich inequality was identified, except for having public health insurance. In the subgroup of adults with private insurance, adults with incomplete primary education, and adults living in households with 7 or more members, the inequality tends to be more significant compared to adults with other types of insurance, adults with more education or adults who live in smaller households, respectively.

Table 2 describes the distribution, and inequality of the actual use, expected use according to need and standardized use according to the need for health care services. The actual use of health care services increases according to income quintile. The wealthiest quintile has a utilization of approximately 15 percentage points higher than the most impoverished quintile. The positive value of ECI (0.1223) indicates pro-rich inequality in the use of health care services. When utilization is adjusted by predisposing and enabling factors, the expected use of health care services is higher among people in poor quintiles. The difference in use between expected and actual use reflects an underutilization of the health care services by the individuals in poor quintiles. After standardizing the use of health care services for health needs, a positive HI was obtained (0.1296), indicating that even when individuals have the same needs, the use of standardized health care services as needed is higher among individuals of richer quintiles.

Table 3 shows the decomposition of the ECI, that is, the inequality in the use of health care services by need and non-need factors. Non-need factors contribute mostly to "pro-rich" inequality $(77.84 \%$ of total pro-rich inequality), while need factors contribute negatively to pro-rich inequality ( $-5.92 \%$ of pro-rich inequality). In particular, the most significant individual contribution to the pro-rich inequality in the use of health care services are the affiliation to social security insurance $(30.66 \%$ of total pro-rich inequality), education (33.25\%) and the per capita income (10.42\% for the highest quintile) (for further details see Figure S1 in the Supplementary material).

\section{Discussion}

This study measured socioeconomic inequality and horizontal inequity related to the use of health care services in Argentina. The results show inequalities in the use of health care services, with the detriment of the vulnerable 
Table 1 Descriptive statistics

\begin{tabular}{|c|c|c|c|c|}
\hline \multirow[b]{2}{*}{ Characteristics } & \multirow{2}{*}{$\begin{array}{l}\text { Total } \\
\text { n }\left(\%^{a}\right)\end{array}$} & \multicolumn{2}{|c|}{ Reported using health care services } & \multirow[b]{2}{*}{$\mathrm{p}$ value } \\
\hline & & $\mathrm{n}\left(\%^{\mathrm{b}}\right)$ & C.I.95\% & \\
\hline General population & $32365(100.00)$ & $16226(49.37)$ & $48.30-50.43$ & \\
\hline \multicolumn{5}{|l|}{ Predisposing factors } \\
\hline \multicolumn{5}{|l|}{ Sex } \\
\hline Male & $14317(47.43)$ & $5914(40.64)$ & $39.07-42.20$ & \multirow[t]{2}{*}{$<0.001$} \\
\hline Female & $18048(52.56)$ & $10312(57.24)$ & $55.84-58.65$ & \\
\hline \multicolumn{5}{|l|}{ Age (in years) } \\
\hline $18-24$ & $4341(16.55)$ & $1690(40.17)$ & $37.28-43.06$ & \multirow[t]{5}{*}{$<0.001$} \\
\hline $25-34$ & $7028(21.90)$ & $3155(42.35)$ & $40.09-44.61$ & \\
\hline $35-49$ & $9013(26.58)$ & $4063(45.45)$ & $43.43-47.47$ & \\
\hline $50-64$ & $6607(19.82)$ & $3707(57.56)$ & $55.29-59.83$ & \\
\hline 65 or more & $5376(15.15)$ & $3611(65.72)$ & $63.24-68.20$ & \\
\hline \multicolumn{5}{|l|}{ Married or cohabitating? } \\
\hline Yes & $17281(58.13)$ & $8579(49.84)$ & $48.44-51.25$ & \multirow[t]{2}{*}{0.299} \\
\hline No & $15084(41.87)$ & $7647(48.70)$ & $47.07-50.33$ & \\
\hline \multicolumn{5}{|l|}{ Educational level } \\
\hline Up to incomplete primary & $3561(9.86)$ & $1909(50.96)$ & $47.63-54.30$ & \multirow[t]{3}{*}{0.002} \\
\hline Complete primary and incomplete secondary & $12287(38.27)$ & $5827(45.66)$ & $43.90-47.42$ & \\
\hline Complete secondary or more & $16517(51.87)$ & $8490(51.80)$ & $50.34-53.26$ & \\
\hline \multicolumn{5}{|l|}{ Household size } \\
\hline 1-3 members & $19124(49.93)$ & $10351(54.77)$ & $53.38-56.16$ & \multirow[t]{3}{*}{$<0.001$} \\
\hline 4-6 members & $11507(42.41)$ & $5197(45.09)$ & $43.36-46.83$ & \\
\hline 7 members or more & $1734(7.66)$ & $678(37.83)$ & $33.87-41.79$ & \\
\hline \multicolumn{5}{|l|}{ Enabling factors } \\
\hline \multicolumn{5}{|l|}{ Type of health coverage ${ }^{c}$} \\
\hline Social security insurance & $19294(56.96)$ & $10685(54.55)$ & $53.16-55.95$ & \multirow[t]{3}{*}{$<0.001$} \\
\hline Private insurance & $3622(13.92)$ & $1958(53.60)$ & $50.76-56.45$ & \\
\hline Public insurance & $9147(29.12)$ & $3454(37.45)$ & $35.48-39.43$ & \\
\hline \multicolumn{5}{|l|}{ Currently employed? } \\
\hline Yes & $20060(62.69)$ & $9203(44.91)$ & $43.57-46.25$ & \multirow[t]{2}{*}{$<0.001$} \\
\hline No & $12305(37.31)$ & $7023(56.86)$ & $55.14-58.58$ & \\
\hline \multicolumn{5}{|l|}{ Urban population } \\
\hline More than 1.5 million inhabitants & $2862(37.33)$ & $1513(50.23)$ & $48.02-52.44$ & \multirow[t]{4}{*}{0.091} \\
\hline Between 500,001 y 1.5 million inhabitants & $6093(19.08)$ & $3171(50.53)$ & $49.04-52.02$ & \\
\hline Between 100,001 y 500,000 inhabitants & $11220(16.76)$ & $5625(48.50)$ & $47.20-49.79$ & \\
\hline Between 5,000 y 100,000 inhabitants & 12190 (26.83) & $5917(47.88)$ & $45.73-50.03$ & \\
\hline \multicolumn{5}{|l|}{ Geographical region } \\
\hline Greater Buenos Aires & $2862(37.33)$ & $1513(50.23)$ & $48.02-52.44$ & \multirow[t]{6}{*}{0.101} \\
\hline Pampeana & $9618(33.43)$ & $5000(50.18)$ & $48.33-52.03$ & \\
\hline Northwest & $6584(10.24)$ & $3051(45.29)$ & $43.77-46.81$ & \\
\hline Northeast & $4014(7.34)$ & $1973(46.10)$ & $43.98-48.22$ & \\
\hline Cuyo & $3339(6.44)$ & $1686(50.15)$ & $47.90-52.39$ & \\
\hline Patagonica & $5948(5.22)$ & $3003(49.62)$ & $47.97-51.27$ & \\
\hline
\end{tabular}


Table 1 Descriptive statistics (Continued)

\begin{tabular}{|c|c|c|c|c|}
\hline \multicolumn{5}{|l|}{ Need factors } \\
\hline \multicolumn{5}{|c|}{ Self-perceived health status } \\
\hline Excellent & $3658(12.08)$ & $1396(38.26)$ & $35.30-41.22$ & \multirow[t]{5}{*}{$<0.001$} \\
\hline Very good & $7477(23.81)$ & $3282(44.16)$ & $41.97-46.34$ & \\
\hline Good & $13967(42.86)$ & $6643(46.58)$ & $44.94-48.22$ & \\
\hline Regular & $6345(18.11)$ & $4172(64.55)$ & $62.21-66.90$ & \\
\hline Bad & 918 (3.12) & $733(82.12)$ & $77.44-86.80$ & \\
\hline \multicolumn{5}{|c|}{ Problems with mobility? } \\
\hline Yes & $3752(11.00)$ & $2713(72.47)$ & $69.64-75.31$ & \multirow[t]{2}{*}{$<0.001$} \\
\hline No & $28613(89.00)$ & $13513(46.51)$ & $45.38-47.65$ & \\
\hline \multicolumn{5}{|c|}{ Feeling lonely or depressed? } \\
\hline Yes & $16616(52.58)$ & $8360(49.54)$ & $48.04-51.04$ & \multirow[t]{2}{*}{0.264} \\
\hline No & $15166(47.42)$ & $7429(48.31)$ & $46.76-49.86$ & \\
\hline \multicolumn{5}{|c|}{ Level of physical activity } \\
\hline Intense & $4522(13.79)$ & $2011(42.77)$ & $40.06-45.48$ & \multirow[t]{3}{*}{$<0.001$} \\
\hline Moderate & 10107 (31.48) & 4969 (49.73) & $47.85-51.61$ & \\
\hline Low & $17467(54.73)$ & $9126(51.00)$ & $49.52-52.48$ & \\
\hline \multicolumn{5}{|c|}{ Pain or physical discomfort? } \\
\hline Yes & $7934(24.06)$ & $5206(65.64)$ & $63.68-67.61$ & \multirow[t]{2}{*}{$<0.001$} \\
\hline No & $24431(75.94)$ & $11020(44.21)$ & $42.98-45.44$ & \\
\hline \multicolumn{5}{|c|}{ Suffers from high blood pressure? ${ }^{d}$} \\
\hline Yes & $10275(34.33)$ & $6318(60.56)$ & $58.71-62.41$ & \multirow[t]{2}{*}{$<0.001$} \\
\hline No & $18291(65.67)$ & $8752(47.42)$ & $46.02-48.82$ & \\
\hline \multicolumn{5}{|c|}{ Suffers from diabetes mellitus? ${ }^{e}$} \\
\hline Yes & $3347(9.80)$ & $2253(68.52)$ & $65.49-71.56$ & \multirow[t]{2}{*}{$<0.001$} \\
\hline No & $28885(90.20)$ & $13941(47.39)$ & $46.26-48.51$ & \\
\hline \multicolumn{5}{|c|}{ Suffers from chronic obstructive pulmonary disease? ${ }^{f}$} \\
\hline Yes & $1408(4.34)$ & $899(62.80)$ & $57.72-67.88$ & \multirow[t]{2}{*}{$<0.001$} \\
\hline No & $30904(95.66)$ & $15302(48.80)$ & $47.71-49.89$ & \\
\hline \multicolumn{5}{|c|}{ Suffers from chronic kidney disease? ${ }^{9}$} \\
\hline Yes & $1782(4.76)$ & $1149(65.19)$ & $60.85-69.52$ & \multirow[t]{2}{*}{$<0.001$} \\
\hline No & $30520(95.24)$ & $15039(48.55)$ & $47.46-49.65$ & \\
\hline \multicolumn{5}{|c|}{ Numbers of chronic diseases suffered } \\
\hline None & $19332(61.67)$ & $8312(42.81)$ & $41.44-44.18$ & \multirow[t]{4}{*}{$<0.001$} \\
\hline One & $9758(29.03)$ & 5586 (55.84) & $53.92-57.77$ & \\
\hline Two & 2814 (7.91) & 1983 (72.08) & $68.87-75.28$ & \\
\hline Three or more & $461(0.13)$ & $345(75.82)$ & $67.71-83.93$ & \\
\hline
\end{tabular}

Source: National Survey of Risk Factors (ENFR) 2013

${ }^{a}$ Column weighted proportion based on the expansion factor of the ENFR 2013

${ }^{\mathrm{b}}$ Raw weighted proportion based on the expansion factor of the ENFR 2013

${ }^{c} n=32063 ;{ }^{d} n=28566 ;{ }^{e}=32232 ;{ }^{f} n=32312 ;{ }^{g} n=32302$

population. When utilization of health care services was standardized according to health needs, pro-rich inequality was identified. The main non-needs factors that contribute to the pro-rich inequality were education, social security insurance, and income.
In particular, our results suggest that the fragmentation of the health care system into three subsectors in terms of financing and service delivery has implications for health care inequality. Among those who have health coverage through social security, there is a marked pro- 


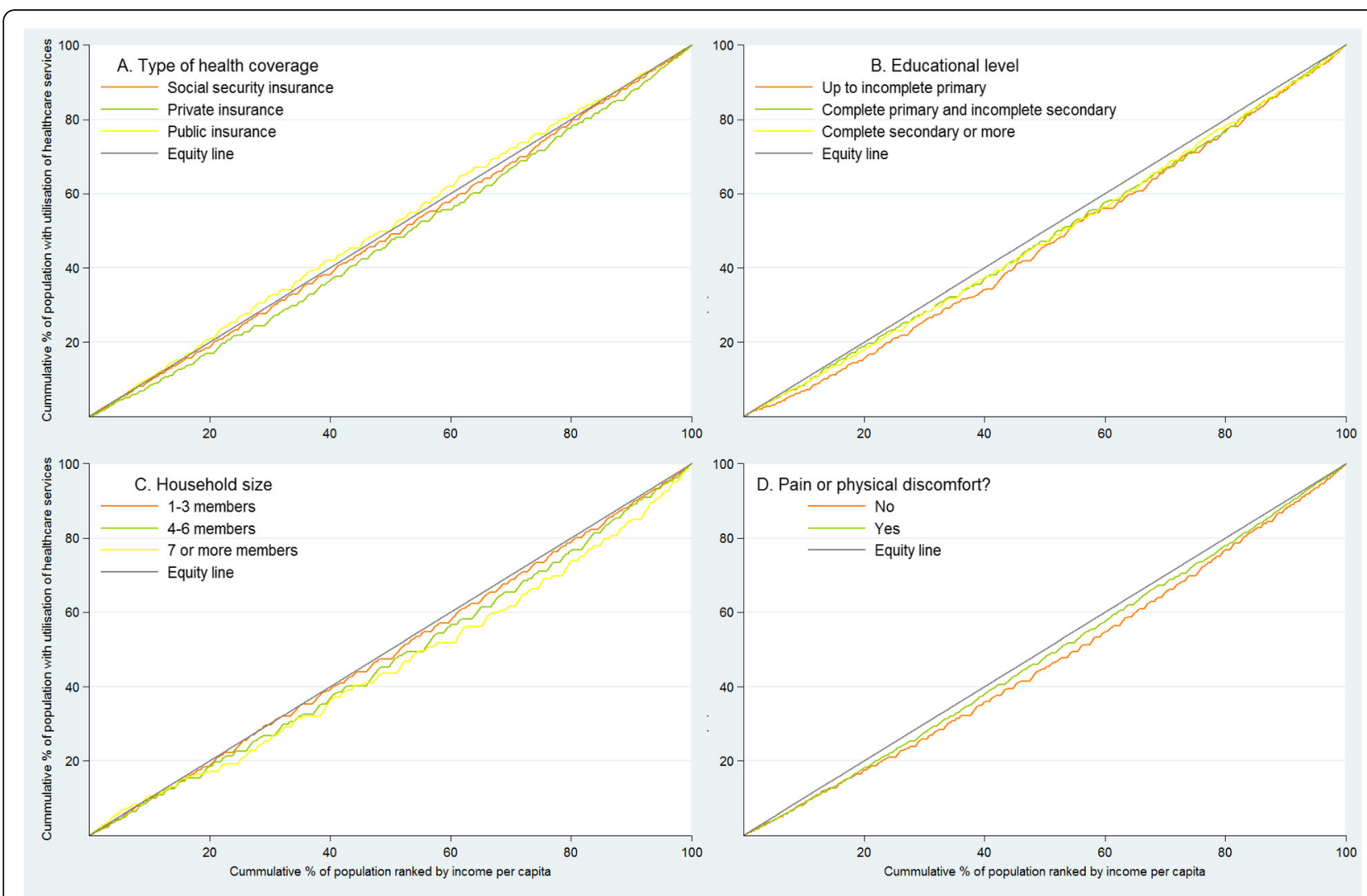

Fig. 2 Concentration curves for the use of health care services in Argentina

rich inequality in the use of health care services. This inequality could be because heterogeneous Obras Sociales, in terms of attention scale, average contribution by affiliate, and benefit coverage, are part of Argentina's social security. These aspects correlate positively with labor income and professions of affiliates [11]. Something similar seems to occur in the private health subsector. In the absence of a regulatory framework for private insurance, private medicine companies compete by offering different health coverage plans and access to providers with differentiated prices, generating a subsector segregated by payment capacity. In general, the population that access to private insurances (and in particular the special coverage plans offered within each private insurance) has the highest income. This fact not only generates disparities in access, use, and quality of services between individuals covered by different subsectors but also between individuals within each subsector $[52,53]$.

On the other hand, our results suggest a negligible contribution of the decentralization of the health care system (represented here through analysis at the geographic region level) to pro-rich inequality. In a literature review on the topic, we identified a local study that concludes that municipal management capacities are a

Table 2 Distribution and inequality of observed utilisation, expected utilisation based on need, and need-standardized utilisation of healthcare services

\begin{tabular}{lllll}
\hline Income per capita quintile & Observed utilisation & Expected utilisation based on need & Difference & Need-standardized utilisation \\
I (poorest) & 0.4192 & 0.5340 & -0.1149 & 0.4290 \\
II & 0.4697 & 0.5141 & -0.0444 & 0.4655 \\
III & 0.5038 & 0.5150 & -0.0113 & 0.5019 \\
IV & 0.5448 & 0.5088 & 0.0361 & 0.5422 \\
V (richest) & 0.5659 & 0.4854 & 0.0806 & 0.5928 \\
Average & 0.4937 & 0.5131 & -0.0194 & 0.5004 \\
ECl / HI & 0.1223 & & 0.1296
\end{tabular}


Table 3 Decomposition of the Erreygers concentration index (ECI)

\begin{tabular}{|c|c|c|}
\hline & \multicolumn{2}{|c|}{ Contribution to the ECI for the utilisation of healthcare services } \\
\hline & Contribution & Contribution as percentage \\
\hline \multicolumn{3}{|l|}{ Need factors } \\
\hline Sex & -0.0029 & $-2.39 \%$ \\
\hline Age $25-34$ years & 0.0004 & $0.32 \%$ \\
\hline Age $35-49$ years & 0.0006 & $0.49 \%$ \\
\hline Age $50-64$ years & 0.0011 & $0.89 \%$ \\
\hline Age 65 years or older & 0.0014 & $1.11 \%$ \\
\hline Self-perceived health status: very good & 0.0027 & $2.24 \%$ \\
\hline Self-perceived health status: good & -0.0019 & $-1.52 \%$ \\
\hline Self-perceived health status: regular & -0.0076 & $-6.25 \%$ \\
\hline Self-perceived health status: bad & -0.0004 & $-0.29 \%$ \\
\hline Problems with mobility & -0.0002 & $-0.16 \%$ \\
\hline Hypertension & -0.0005 & $-0.39 \%$ \\
\hline Diabetes mellitus & 0.0001 & $0.11 \%$ \\
\hline Chronic obstructive pulmonary disease & 0.0000 & $-0.01 \%$ \\
\hline Chronic kidney disease & -0.0001 & $-0.08 \%$ \\
\hline Subtotal & -0.0072 & $-5.92 \%$ \\
\hline \multicolumn{3}{|l|}{ Non-need factors } \\
\hline Married or cohabiting & 0.0001 & $0.07 \%$ \\
\hline Household size: 4-6 members & 0.0051 & $4.17 \%$ \\
\hline Household size: 7 or more members & 0.0011 & $0.89 \%$ \\
\hline Complete primary and incomplete secondary & -0.0082 & $-6.71 \%$ \\
\hline Complete secondary or more & 0.0407 & $33.25 \%$ \\
\hline Social security insurance & 0.0375 & $30.66 \%$ \\
\hline Private insurance & 0.0054 & $4.38 \%$ \\
\hline Currently employed & -0.0035 & $-2.89 \%$ \\
\hline II income per capita quintile & 0.0012 & $0.97 \%$ \\
\hline III income per capita quintile & 0.0000 & $0.01 \%$ \\
\hline IV income per capita quintile & 0.0027 & $2.20 \%$ \\
\hline V income per capita quintile & 0.0128 & $10.42 \%$ \\
\hline Pampeana region & -0.0002 & $-0.17 \%$ \\
\hline Northwest region & 0.0005 & $0.43 \%$ \\
\hline Northeast region & 0.0002 & $0.16 \%$ \\
\hline Cuyo region & -0.0001 & $-0.04 \%$ \\
\hline Patagonica region & 0.0001 & $0.05 \%$ \\
\hline Subtotal & 0.0952 & $77.84 \%$ \\
\hline Residual & 0.0344 & $28.08 \%$ \\
\hline
\end{tabular}

Values $<0$ suggest "pro-poor" utilization and $>0$ suggest "pro-rich" utilization

good predictor of the use of health care services in lowincome populations [44], and a regional study that suggests that decentralization in Chile, Colombia and Bolivia relates to an improvement in some equity indicators [54]. However, as already mentioned, we carried out our analysis at the regional level (and not at the provincial level because of sample size), so, likely, our approach does not account for the effect that decentralization could have on inequality at a smaller geographical scale (for example at the provincial or municipal level).

Another factor that contributes to pro-rich inequality is formal education. A possible explanation could be the existence of high educational segregation in Argentina. Even though access to free and public education is 
guaranteed to the entire population, in the last decades, an important process of selective migration of students of high socioeconomic levels towards private education institutions has been identified $[55,56]$. The private education institutions of Argentina present characteristics and strategies of education (educational content, the extension of the school day, extra-curricular activities, among many others) that differ from what is offered by the public education institutions [57]. In addition, given the differences in the teaching strategy and the socioeconomic composition of the students, it is likely that those who study in private institutions have a higher endowment of human capital and social capital than those who study in public institutions [58]. This could translate into better employment and income opportunities for this subpopulation, increasing access and utilization of health services.

In general, our results of socioeconomic inequality and inequity related to the use of health services are superior to those reported in previous studies in Argentina [3840]. Differences in the socio-economic characteristics of the individuals considered in each study could constitute a possible explanation. Two studies $[39,40]$ used data on the use of services by older adults, so that comparability with our results may be limited. Despite this, our results on the determinants that most contribute to prorich inequalities (health coverage, education, and income) are similar to those reported by other studies at the local [38-40] and regional level, such as Brazil [5962], Chile [63, 64], Colombia [65, 66], Ecuador $[67,68]$ and Mexico [69].

The findings of this study are relevant for policy discussion at a local and regional level. First, it is necessary to strengthen and expand public health coverage programs that are specific to vulnerable population subgroups such as pregnant women, children, or poor individuals. This process should involve the Nation, provinces and municipalities, who should agree on prioritized population groups, healthcare lines, and articulate the use of available resources. In the last 15 years, the Argentine government has implemented the Nacer / SUMAR Program, a pay-for-performance program that operates within the federal system of the country, and provides health coverage to pregnant women and children. Program evaluations have shown favorable results $[70,71]$, and it is currently considered as a platform to reach the UHC at the local level [46]. Secondly, the design and implementation of cross-subsidy mechanisms between the health subsectors, mainly between the public and social security subsectors, is required in order to compensate for the socio-economic inequalities observed among population groups, improving coordination and integration between sectors [7]. Local experience in this direction is the Sistema Único de
Recupero (SUR, acronym in Spanish) Program, which consists of providing financial coverage for high-cost diseases within the union social security subsector. The Superintendence of Health Services, which is the national regulatory entity of social security institutions, manages this program. An external evaluation of this program suggests that it seems to have contributed to greater equity among OSN with different financing capacities [72].

Third, the design and implementation of benefits packages at prioritized pathologies level are suggested, in order to guarantee a package of high-quality health services to the entire population regardless of the type of coverage and place of residence. Some countries in the region have made progress in these initiatives as a means to reduce health care inequalities. For example, in 2002, Chile established a right guarantee mechanism known as the Plan de Aseguramiento Universal de Garantías Explícitos (AUGE, acronym in Spanish). On that occasion, a set of 57 protocolized pathologies was selected, and it was assumed that all citizens have access to the same treatments regardless of whether they are provided by the public system or by the private one, with satisfactory results in terms of reducing health inequalities [73].

This study has limitations that need consideration. First, the survey used (ENFR 2013) does not collect information on additional variables that could affect the effective use of health care services, such as accessibility to services, the perception of the quality of services by individuals, among others. Second, the survey used does not report information on the use of health care services by individuals under 18 , so that subpopulations of interest, potentially vulnerable such as children and adolescents, were not included in our study. Third, the use of cross-sectional data in our analysis prevents us from discussing our findings in terms of potential causal relationships. Fourth, the ENFR 2013 does not present detailed information on household members (particularly sex and age), which does not allow to perform the analysis with per capita income adjusted for equivalent adult. However, we replicated our analysis following the equivalent adult adjustment criteria proposed by the Organization for Economic Cooperation and Development (OECD) [74], and the conclusions of our study remained unchanged. Fifth, the survey only provides information about health conditions by self-report, which could bias our estimates. The latest version of the survey (ENFR 2018, recently available) has two types of health condition measurements (by biomarkers and by selfreport) for a subsample of individuals. According to the data of this survey, the self-report implies an underestimation for some health conditions, for example, 4.5 percentage points (p.p.) for the case of overweight or obesity, 5.8 (p.p.) for hypertension, and 4.3 (p.p.) for 
diabetes [75]. Based on this, future studies become necessary to analyze the implications of these differences in the health condition on the measurement of health inequality at the local level. Sixth, the validity of the Andersen theoretical model used in this study could face challenge based on the characteristics of the local health system, the socio-economic aspects of the population, and its epidemiological profile. In this regard, countries such as Mexico have adapted Andersen's theoretical model to apply it to their local context [76]. However, local studies have been identified that have used this theoretical framework to explain the use of health care services [44-46], without making adaptations.

In conclusion, the Argentine health system shows prorich inequality in the use of health care services. To keep the commitment of "not to leave anyone behind", it is necessary to design strategies to improve articulation between the three coverage subsectors, and national, provincial and municipal governments. The results showed here could provide lessons for countries with similar contexts and challenges in public health.

\section{Supplementary information}

Supplementary information accompanies this paper at https://doi.org/10. 1186/s12939-020-01168-6.

Additional file 1: Table S1. Basic indicators. Argentina, Latin American and the Caribbean countries (average) and Organization for Economic Cooperation and Development (OECD) country members (average).

Additional file 2: Figure S1. Decomposition of the Erreygers concentration index (ECl).

\section{Acknowledgments}

The authors thank Andrés Pichon-Riviere, Federico Augustovski, Facundo Crosta and Caitlin Williams for their comments to previous versions of this manuscript. The authors also thank the anonymous reviewers for their helpful advice.

\section{Authors' contributions}

AP formulated the research concept. All authors critically contributed to the design of the study. NE and CRR performed the statistical analysis. All authors critically contributed to the interpretation of the results, drafted the manuscript, read and approved the final manuscript.

\section{Funding}

The authors declare that they have no specific financial support for this research.

\section{Availability of data and materials}

The data utilized in this study was from the Third National Survey of Risk Factors 2013 (ENFR 2013) designed and compiled by the National Institute of Statistics and Census (INDEC) and the Ministry of Health of Argentina. Data are available at:

https://www.indec.gob.ar/indec/web/Institucional-Indec-BasesDeDatos-2

\section{Ethics approval and consent to participate}

Not applicable.

\section{Consent for publication}

Not applicable.

\section{Competing interests}

The authors declare that they have no competing interests.

Received: 11 October 2019 Accepted: 23 March 2020

Published online: 31 July 2020

\section{References}

1. Mújica ÓJ, Moreno CM. From words to action: measuring health inequalities to "leave no one behind". Rev Panam Salud Publica. 2019;43:e12. Available from: https://doi.org/10.26633/RPSP.2019.12.

2. United Nations. Transforming our world: The 2030 agenda for Sustainable Development (A/RES/70/1). 2015.

3. Atun R, de Andrade LOM, Almeida G, Cotlear D, Dmytraczenko T, Frenz $P$, et al. Health-system reform and universal health coverage in Latin America. The Lancet. 2015;385(9974):1230-47. Available from: https://doi.org/10.1016/ S0140-6736(14)61646-9.

4. Titelman D, Cetrángolo O, Acosta OL. Universal health coverage in Latin American countries: how to improve solidarity-based schemes. The Lancet. 2015;385(9975):1359-63. Available from: https://doi.org/10.1016/S0140-6736 (14)61780-3.

5. World Bank. World Development Indicators. World Bank; 2019. Available from: https://databank.bancomundial.org/databases. Cited 2019 Jan 20.

6. Novick GE. Health Care Organization and Delivery in Argentina: A Case of Fragmentation, Inefficiency and Inequality. Glob Policy. 2017;8:93-6. Available from: https://doi.org/10.1111/1758-5899.12267.

7. Rubinstein A, Zerbino MC, Cejas C, López A. Making universal health care effective in Argentina: a blueprint for reform. Health Syst Reform. 2018;4(3): 203-13. Available from: https://doi.org/10.1080/23288604.2018.1477537.

8. Maceira D. Descentralización y Equidad en el Sistema de Salud Argentino: Centro de Estudios de Estado y Sociedad (CEDES); 2014. Available from: https://www.danielmaceira.com.ar/wp-content/uploads/2014/07/MaceiraArgentina2005final.pdf.

9. Belló M, Becerril-Montekio V. Sistema de salud de Argentina. Salud Pública de México. 2011;53(2)

10. Cetrangolo O. Financiamiento fragmentado, cobertura desigual y falta de equidad en el sistema de salud argentino. Revista de Economía Política de Buenos Aires. 2014:8(13):145-83.

11. Maceira D. Morfología del Sistema de Salud Argentino Descentralización, Financiamiento y Gobernanza. Documento de trabajo CEDES 141; 2018 Available from: http://repositorio.cedes.org/bitstream/123456789/4460/1/ Doc_t141.pdf.

12. Ministerio de Salud de la Nación de Argentina. Análisis de situación salud: República Argentina. 2018. Available in: http://www.msal.gob.ar/images/ stories/bes/graficos/0000001392cnt-Anlisis\%20de\%20situacin\%20de\%2 0salud\%20-\%20Repblica\%20Argentina\%20-\%20ASIS\%202018.pdf.

13. INDEC. Censo Nacional de Población, Hogares y Viviendas. 2010. Available from: https://www.indec.gob.ar/indec/web/Nivel3-Tema-2-41.

14. De la Puente C, de los Reyes L. ¿Cuánto gasta Argentina en Salud? Dirección de Economía de la Salud, Ministerio de salud de la Nación; 2019. Available from: http://www.msal.gob.ar/images/stories/bes/graficos/0000001 756cnt-cuanto-gasta-argentina-en-salud.pdf.

15. Maceira D. Financiamiento, Aseguramiento y Prestación de Servicios de Salud en Argentina. Centro de Estudios de Estado y Sociedad; 2010 Available from: http://repositorio.cedes.org/bitstream/123456789/3882/1/ SSPP200207.pdf.

16. Ministerio de Salud de la Nación de Argentina. Gasto consolidado en salud de las provincias - Año 2015. Buenos Aires: Ministerio de Salud de Argentina; 2017

17. Observatorio Federal de Recursos Humanos en Salud. Ministerio de Salud de Argentina. Fuerza de trabajo en el sector salud en Argentina. Datos 2016. 2018. Available from: https://www.argentina.gob.ar/sites/default/ files/20180918-fuerza-trabajo-sector-salud-2016.pdf.

18. Dirección de Estadísticas e Información de Salud (DEIS). Ministerio de Salud de Argentina. Natalidad y Mortalidad 2017. Síntesis estadística No. 5. 2017. Available from: http://www.deis.msal.gov.ar/wp-content/uploads/2019/04/ Sintesis-nro-5-natalidad-y-mortalidad-2017.pdf

19. Instituto Nacional de Cáncer. Ministerio de Salud de Argentina. Boletín de vigilancia epidemiológica. Análisis de situación de salud por cáncer. 2018. Available from: http://www.msal.gob.ar/images/stories/bes/graficos/ 0000001386cnt-20181213-boletin-epidemiologia.pdf. 
20. Maceira D, Espinola N, Palacios A. Costo-efectividad de las pruebas de tamizaje del cáncer colorrectal en la Argentina. Acta Gastroenterol Latinoam 2016;46:8-17. Available from: http://www.actagastro.org/numerosanteriores/2016/Nol-46-N1/Nol46N1-PDF05.pdf.

21. Arrossi S, Paolino M, Sankaranarayanan R. Challenges faced by cervical cancer prevention programs in developing countries: a situational analysis of program organization in Argentina. Rev Panam Salud Publica. 2010;28(4): 249-57. Available from: https://doi.org/10.1590/s1020-49892010001000003.

22. Maurizio R. Transitions to formality and declining inequality: Argentina and Brazil in the 2000s. Dev Change. 2015;46(5):1047-79. Available from: https:// doi.org/10.1111/dech.12195.

23. Gasparini L, Guillermo C, Tornarilli L, Mejía D. Trends in Income Inequality in Latin America. Economía. 2011;11. Available from: http://www.jstor.org/ stable/41343452

24. Alvaredo F, Gasparini L. Recent Trends in Inequality and Poverty in Developing Countries. In: Handbook of Income Distribution; vol. 2: Elsevier; 2015. p. 697-805. Available from: https://linkinghub.elsevier.com/retrieve/pii/ B9780444594280000102.

25. Gasparini L, Lustig N. The Rise and Fall of Income Inequality in Latin America. CEDLAS - Centro de Estudios Distributivos, Laborales y Sociales, Universidad Nacional de La Plata; 2011. Documento de Trabajo 118.

26. Cruces G, Gasparini L. A Distribution in Motion: The Case of Argentina. CEDLAS - Centro de Estudios Distributivos, Laborales y Sociales, Universidad Nacional de La Plata; 2008. Documento de Trabajo 78.

27. Findling L, Abramzón M, Peterlini C. Desigualdades en salud: de la teoría a los indicadores. In: ¿Para qué la sociología en la Argentina actual? Universidad de Buenos Aires (UBA); 2004.

28. Mazzeo V. La situación de la salud-enfermedad-atención en la Ciudad de Buenos Aires entre 1990 y 2002. Salud Colect. 2007;3(3):285-300.

29. Arrossi S, Ramos S, Paolino M, Sankaranarayanan R. Social inequality in pap smear coverage: identifying under-users of cervical cancer screening in Argentina. Reprod Health Matters. 2008;16(32):50-8. Available from: https:// doi.org/10.1016/S0968-8080(08)32410-0

30. Jorrat R, Fernández MM, Marconi E. Utilización y gasto en servicios de salud de los individuos en Argentina en 2005. Comparaciones internacionales de diferenciales socio-económicos en salud. Salud Colect. 2008:4(1):57-96.

31. Adaszko D. La salud de la población y el acceso al sistema que la atiende. In: Estado de Situación del Desarrollo Humano y Social: Barreras estructurales y dualidades de la sociedad argentina en primer año del Bicentenario. EDUCA: Ciudad Autónoma de Buenos Aires; 2011.

32. Checa S. Uso y gestión de los servicios de salud pública en la atención del embarazo y regulación de la fecundidad. Rev Hosp Mat Inf Ramón Sardá. 1996;15(1):12-7.

33. Epele M. Sobre Barreras Invisibles y Fracturas Sociales: Criminalización del Uso de Drogas y Atención Primaria de la salud. In: Atención Primaria en Salud Enfoques Interdisciplinarios. Ciudad Autónoma de Buenos Aires; 2007. p. 147-69.

34. Monsalvo M. Continuidad de los cuidados farmacológicos de pacientes crónicos en el Primer Nivel de Atención: El rol de la oferta y los condicionantes estructurales en Argentina. Tesis de Maestría en Epidemiología en Salud Pública. Ministerio de Salud de la Nación de Argentina; 2010

35. Báscolo E, Yavich N, Urquía M. Capacidades locales de gestión como factor predictivo de la utilización y accesibilidad a los servicios de primer nivel para la obtención de cuidados prenatales. Rev Gerenc Polit Salud. 2007; 6(12):112-25.

36. Barcala A, Stolkiner A. Reforma del sector y utilización de servicios de salud en fmilias NBI: estudio de caso. In: La salud en crisis. Ciudad Autónoma de Buenos Aires: Editorial Dunken; 2000.

37. FIEL. La desigualdad en la salud. Fundación de Investigaciones Económicas Latinoamericana (FIEL); 2007. Available from: http://www.fiel.org/ publicaciones/Libros/LIBRO_1310053073180.pdf.

38. De Santis M, Herrero V. Desigualdad y Utilización de los Servicios de Salud Una Aplicación al Caso Argentino en 2001. Revista De Economía y Estadística. 2009;47(1):125-62. Available from: https://revistas.unc.edu.ar/ index.php/REyE/article/view/3860

39. Balsa Al, Rossi M, Triunfo P. Horizontal Inequity in Access to Health Care in Four South American Cities. ECINEQ. 2009; Working paper 131. Available from: https://doi.org/10.2139/ssrn.1474425.

40. De Santis M. Equidad y utilización en la utilización de servicios preventivos de salud. El caso de los adultos mayores en Latinoamérica en el año 2000. XLV Reunión Anual de la Asociación Argentina de Economía Política (AAEP); 2010.
41. Ministerio de Salud de la Nación de Argentina. Tercera Encuesta Nacional de Factores de Riesgo para Enfermedades No Transmisibles. 2015. Available from: http://www.msal.gob.ar/images/stories/bes/graficos/0000000544cnt-3 ra-encuesta-nacional-factores-riesgo_2013_informe-completo.pdf. Cited 2019 Jun 6.

42. Andersen R. A behavioral model of families' use of health services: Center for Health Administration Studies, University of Chicago; 1968. p. 111. Available from: https://www.jstor.org/stable/pdf/145064.pdf?seq=1.

43. Andersen R. Revisiting the behavioral model and access to medical care: does it matter? J Health Soc Behav. 1995;36(1):1-10. Available from: https:// www.ncbi.nlm.nih.gov/pubmed/7738325.

44. Báscolo EP, Yavich N, Urquía ML. Capacidades locales de gestión como factor predictivo de la utilización y accesibilidad a los servicios de primer nivel para la obtención de cuidados prenatales. Revista Gerencia y Políticas de Salud. 2007;6(12). Available from: https://www.redalyc.org/ pdf/545/54561205.pdf.

45. Ballesteros M. Un análisis sobre las desigualdades en el acceso a los servicios de salud en la población adulta urbana de Argentina a partir de datos secundarios: Instituto de Investigaciones Gino Germani, Facultad de Ciencias Sociales, UBA; 2014. Documentos de Jóvenes Investigadores 41. Available from: http://biblioteca.clacso.edu.ar/Argentina/iigg-uba/20151022 054933/dji41.pdf.

46. Jahangir E, Irazola V, Rubinstein A. Need, enabling, predisposing, and behavioral determinants of access to preventative care in Argentina: analysis of the national survey of risk factors. PLoS One. 2012;7(9):e45053. Available from: https://doi.org/10.1371/journal.pone.0045053.

47. Ministerio de Salud de la Nación de Argentina. Encuesta Nacional de Factores de Riesgo. In: Documento para la utilización de la base de datos de usuarios. Ministerio de Salud de la Nación e Instituto Nacional de Estadísticas y Censos; 2013. Available from: https://www.indec.gob.ar/ftp/ cuadros/menusuperior/enfr/doc_base_usuario_enfr2013.pdf.

48. International Physical Activity Questionnaire. Available from: https://sites. google.com/site/theipaq/. Cited 2019 Jun 22.

49. O'Donnell O, van Doorslaer E, Wagstaff A, Lindelow M. Analyzing Health Equity Using Household Survey Data. The World Bank; 2007. World Bank Institute Development Studies. Available from: https://doi.org/10.1596/9780-8213-6933-3.

50. Kakwani N, Wagstaff A, van Doorslaer E. Socioeconomic inequalities in health: measurement, computation, and statistical inference. J Econom. 1997;77(1):87-103. Available from: http://www.sciencedirect.com/science/ article/pii/S0304407696018076.

51. O'Donnell O, O'Neill S, Van Ourti T, Walsh B. Conindex: estimation of concentration indices. Stata J. 2016;16(1):112-38. Available from: https:// www.ncbi.nlm.nih.gov/pubmed/27053927.

52. Machado CV. Health policies in Argentina, Brazil and Mexico: different paths, many challenges. Ciênc saúde coletiva. 2018;23(7):2197-212. Available from: https://doi.org/10.1590/1413-81232018237.08362018.

53. WHO. A National Social Health Insurance Plan for Argentina: Simulating its financial feasibility: The World Health Organization; 2010. Discussion Paper 4 Available from: https://www.who.int/health_financing/documents/dp_e_10_ 04-shi_arg.pdf.

54. Bossert TJ. Decentralization of health Systems in Latin America: a comparative study of Chile, Colombia, and Bolivia. LAC health sector reform initiative; 2000. Available from: https://www.paho.org/hq/dmdocuments/201 0/29-Decentralization_Health_Systems_LA-Comparative_Analysis_Chile_ Colombia_Bolivia.pdf.

55. Gasparini L, Jaume D, Serio M, Vásquez E. La segregación entre escuelas públicas y privadas en Argentina. Reconstruyendo la evidencia. Desarrollo Econ. 2011;51: 202-3. Available from: https:/www.jstor.org/stable/23612381?seq=1.

56. Jaume D, Gasparini L. Un Estudio sobre el Incremento de la Segregación Escolar en Argentina: CEDLAS - Centro de Estudios Distributivos, Laborales y Sociales, Universidad Nacional de La Plata; 2013. Documento de Trabajo 143. Available from: https://www.econstor.eu/handle/10419/127665.

57. Ziegler S. Personalization and competition in elite schools in Buenos Aires: school strategies for the production and legitimization of dominant groups. J Educ Work. 2017;30(2):145-55. Available from: https://doi.org/10.1080/ 13639080.2017.1278904.

58. Marchionni M, Vazquez E, Pinto F. Desigualdad educativa en la Argentina. Análisis en base a los datos PISA 2009. 2012. MPRA Working Paper 56420. Available from: https://mpra.ub.uni-muenchen.de/56420/1/Draft_ desigualdad_educativa_Argentina_11_mayo_2012.pdf. 
59. Cataife G, Courtemanche C. Is Universal Health Care in Brazil Really Universal? 2011. Available from: https://papers.ssrn.com/abstract=1690662. Cited 2019 Sep 29.

60. Travassos C, Viacava F, Pinheiro R. Utilization of health care services in Brazil: gender, family characteristics, and social status. Revista panamericana de. 2002; Available from: https://europepmc.org/abstract/med/12162833.

61. Macinko J, Lima-Costa MF. Horizontal equity in health care utilization in Brazil, 1998-2008. Int J Equity Health. 2012;11:33. Available from: https://doi. org/10.1186/1475-9276-11-33

62. Paim J, Travassos C, Almeida C, Bahia L, Macinko J. The Brazilian health system: history, advances, and challenges. The Lancet. 2011;377(9779):177897. Available from: https://doi.org/10.1016/S0140-6736(11)60054-8.

63. Gallardo K, Varas L, Gallardo M. Inequality of opportunity in health: evidence from Chile. Rev Saude Publica. 2017;51:110. Available from: https://doi.org/ 10.11606/S1518-8787.2017051007034.

64. Núñez A, Chi C. Equity in health care utilization in Chile. Int J Equity Health. 2013;12:58. Available from: https://doi.org/10.1186/1475-9276-12-58.

65. Ruiz Gómez F, Zapata Jaramillo T, Garavito Beltrán L. Colombian health care system: results on equity for five health dimensions, 2003-2008. Rev Panam Salud Publica. 2013;33(2):107-15. Available from: https://doi.org/10.1590/ s1020-49892013000200005.

66. Mejía-Mejía A, Sánchez-Gandur AF, Tamayo-Ramírez JC. Equity in access to health-services in Antioquia, Colombia. Revista de Salud Pública. 2007;9(1): 26-38. Available from: http://www.scielo.org.co/scielo.php?script=sci arttext\&pid=s0124-00642007000100005.

67. Lopez-Cevallos D, Chi C. Inequity in health care utilization in Ecuador: an analysis of current issues and potential solutions. Int J Equity Health. 2012; 11(Suppl 1):A6. Available from: https://doi.org/10.1186/1475-9276-11-S1-A6.

68. Granda ML, Jimenez WG. The evolution of socioeconomic health inequalities in Ecuador during a public health system reform (2006-2014). Int J Equity Health. 2019;18(1):31. Available from: https://doi.org/10.1186/ s12939-018-0905-y.

69. Barraza-Lloréns M, Panopoulou G, Díaz BY. Income-related inequalities and inequities in health and health care utilization in Mexico, 2000-2006. Rev Panam Salud Publica. 2013;33(2):122-30. Available from: https://doi.org/10. 1590/s1020-49892013000200007.

70. Gertler P, Giovagnoli P, Martinez S. Rewarding provider performance to enable a healthy start to life: evidence from Argentina's plan Nacer. Policy Res Working Papers. 2014. Working paper 6884. Available from: https://doi. org/10.1596/1813-9450-6884

71. Celhay PA, Gertler PJ, Giovagnoli P, Vermeersch C. Long-run effects of temporary incentives on medical care productivity. Am Econ J Appl Econ. 2019;11(3):92-127. Available from: https://doi.org/10.1257/app.20170128.

72. Maceira D. Cobertura de enfermedades de alto costo, y el accionar de Sistema Único de Reintegros en Argentina: Centro de Estudios de Estado y Sociedad (CEDES); 2018. Documentos de Trabajo 143. Available from: http:// repositorio.cedes.org/bitstream/123456789/4462/1/Doc_t143.pdf.

73. Bossert TJ, Leisewitz T. Innovation and change in the Chilean health system. N Engl J Med. 2016;374(1):1-5. Available from: https://doi.org/10.1056/ NEJMp1514202.

74. OECD. OECD Framework for Statistics on the Distribution of Household Income, Consumption and Wealth; 2013. Available from: https://doi.org/10, 1787/9789264194830-en

75. INDEC. Cuarta Encuesta Nacional de Factores de Riesgo. Resultados definitivos. Instituto Nacional de Estadística y Censos - INDEC: Ciudad Autónoma de Buenos Aires; 2019.

76. Tamez-González S, Valle-Arcos Rl, Eibenschutz-Hartman C, Méndez-Ramírez I. Adaptación del modelo de Andersen al contexto mexicano: acceso a la atención prenatal: Salud Pública de México; 2006. Available from: http:// www.scielo.org.mx/scielo.php?script=sci_arttext\&pid=\$0036-363420060005 00008\&lng=es.

\section{Publisher's Note}

Springer Nature remains neutral with regard to jurisdictional claims in published maps and institutional affiliations.

\section{Ready to submit your research? Choose BMC and benefit from:}

- fast, convenient online submission

- thorough peer review by experienced researchers in your field

- rapid publication on acceptance

- support for research data, including large and complex data types

- gold Open Access which fosters wider collaboration and increased citations

- maximum visibility for your research: over $100 \mathrm{M}$ website views per year

At BMC, research is always in progress.

Learn more biomedcentral.com/submissions 